\title{
Investigation of Nomophobia Levels of Vocational School Students According to Demographic Characteristics and Intelligent Phone Use Habits
}

\author{
Ezgi Pelin Yildiz ${ }^{1}$, Metin Çengel ${ }^{1} \&$ Ayşe Alkan $^{1}$ \\ ${ }^{1}$ Department of Computer Programming, Kafkas University Kazım Karabekir Vocational School of Technical \\ Sciences, Kars, Turkey \\ ${ }^{2}$ Department of Computer Programming, Hendek Vocational High School, Sakarya Applied Science University, \\ Sakarya, Turkey \\ ${ }^{3}$ Samsun Provincial Directorate of National Education, Samsun, Turkey \\ Correspondence: Ezgi Pelin Yildiz, Department of Computer Programming, Kafkas University Kazım Karabekir \\ Vocational School of Technical Sciences, Kars, Turkey. Tel: 90-0474-225-1150. E-mail: \\ yildizezgipelin@gmail.com
}

Received: January 11, 2020

Accepted: February 6, $2020 \quad$ Online Published: February 20, 2020

doi:10.5539/hes.v10n1p132

URL: https://doi.org/10.5539/hes.v10n1p132

\begin{abstract}
Nomophobia, which is accepted as the disease of today, is defined as the fear of being deprived of mobile phone. The aim of this study is to reveal the changes of nomophobia levels of Vocational School students according to demographic characteristics and smartphone usage habits. The study group consisted of 250 students studying at Hendek Vocational School of Sakarya University. The research was conducted in relational survey model. In this research, Measuring Problematic Mobile Phone Use: Development and Preliminary Psychometric Properties of the PUMP Scale developed by Stone and Bibbey (2013) was used as data collection tool. The scale consists of 20 items, 5-point Likert scale "Strongly Disagree-Disagree-Undecided-Agree-Strongly Agree" was used in answering the scale items. The scale supports a single factor structure. Internal consistency coefficient was found to be excellent $(\alpha=.94)$ and strong correlations between items $(r=.76, \mathrm{p}<.00)$. According to the results of the study, there was no significant difference between demographic characteristics such as gender, age, department and nomophobia. However, the habits of using smart phones; it was found that there was a significant difference between year of use-charging intervals-checking intervals and forgetfulness panic states and nomophobia levels.
\end{abstract}

Keywords: nomophobia, smart phone, smart phone usage habits, vocational school students

\section{Introduction}

Rapid developments and changes in information technologies have brought many changes and ease in individuals' lives. Especially mobile devices such as tablet computers, notebooks, PDAs, smart phones have become indispensable devices of our lives. It is obvious that this situation can be explained by statistical data. When TUIK 2019 data are analyzed; 98\% of adults use mobile phones and 77\% use smart phones. This devotion of individuals to smart phones has caused some psychological disorders.

University of Connecticut researcher David Greenfield described this psychological disorder in English with the word "Nomophobia", a combination of the words "NO MOBILE PHONE". The definition of nomophobia in clinical psychology; "Is defined as irrational and involuntary fear that individuals experience when they cannot access their smartphones and / or cannot communicate with others via their smartphones (King et al., 2013; Yildirim and Correia, 2015). When the related literature is examined, it is observed that nomophobia has different behaviors and symptoms. Individuals who exhibit nomophobic behavior and symptoms suddenly start to worry when their smartphones are not with them, when the batteries run out and / or when the devices are out of range, and even need to control the devices obsessively even if they are with them (Adnan and Gezgin, 2016; Dixit et al., 2010; Gezgin and Çakır, 2016; Pavithra and Madhukumar, 2015; Sharma, Sharma, Sharma and Wavare, 2015; Yildirim, Sumuer, Adnan, and Yildirim, 2015). In addition to such behaviors, the presence of symptoms such as dizziness, shortness of breath, stomach cramps, and anxiety in the health dimension is also noteworthy in the name of nomophobia (Thomee, Harenstam and Hagberg, 2011). 
In recent studies, it has been shown that nomophobia is effective in human life. When the field is examined; Schifferstein et al. (2006) and Lee et al. (2014) in their study, the level of nomophobia showed a significant difference in terms of female students; Kwon et al. (2013) and Takao et al. (2009) showed that the level of nomophobia is significant in terms of male students. Similar to the results of the study, Dixit et al. (2010) found that the nomophobia levels of health sciences students were not significant in terms of gender variable. Similarly; Uysal et al. (2016) by 265 students, Pavithra et al. (2015), no significant relationship was found between gender variable and nomophobia level in 200 studies.

In a survey conducted by the SecurEnvoy research company in the UK with 1000 people in 2012, 66\% of the participants had high levels of nomophobia. A study on university students in France found that one out of every three students was nomophobic (Tavolacci, Meyrignac, Richard, Dechelotte, and Ladner, 2015). In their research, Kaplan-Smart and Gezgin (2016) studied 683 university students in the context of examining the relationship between the university students' nomophobia levels and different behavioral patterns. As a result; Two sub-dimensions: "inability to access information and communication" in terms of nomophobia has been found to be widespread among university students. Anshari, Alas and Sulaiman (2019) examined the effects of smartphone addiction and nomophobia on young people. As a result; feeling insecure, panic-fear-anxiety, anti-sociality, addiction-social media addiction, health problems have been put forward as the leading behaviors and symptoms of nomophobia.

Burucuoğlu (2017) conducted a research on the nomophobia levels of vocational high school students. As a result, it was found that the nomophobia levels of associate degree students were above average. In addition, significant differences were found between male and female individuals in terms of nomophobia levels.

Celik and Atilla (2018) worked with 311 Vocational High School students to investigate the relationship between university students' nomophobia, emotion regulation difficulty and academic achievement. According to the findings of the study, it was seen that female students had higher nomophobia levels than male students in terms of gender. In addition, the findings revealed that they were nomophobic, frequently checking their mobile phones during the day, spending most of their time on the internet, carrying a charger, and checking their mobile phones as soon as woke up. There was a statistically significant and positive weak relationship between nomophobia and emotion regulation difficulty. For all that there was no statistically significant relationship between academic achievement and nomophobia and emotion regulation difficulty.

In his research, Akman (2019) investigated the effect of the no mobile phone (nomophobia) on the academic achievement of university students. In this context, students of Suleyman Demirel University, political science and public administration departments were studied. As a result, students were found to be extremely nomophobic. Female students were more nomophobic than male students. As a result of the analysis, no correlation was found between the levels of nomophobia and achievement levels.

\section{Method}

This research was carried out with relational scanning method, one of the quantitative research methods. The relational screening method is used to determine the relationships between variables and to predict possible outcomes (Cresswell, 2017).

\subsection{Data Collection Tool}

In this research, Measuring Problematic Mobile Phone Use: Development and Preliminary Psychometric Properties of the PUMP Scale developed by Stone and Bibbey (2013) was used as data collection tool. The scale consists of 20 items, 5-point Likert scale "Strongly Disagree-Disagree-Undecided-Agree-Strongly Agree" was used in answering the scale items. The scale supports a single factor structure. Internal consistency coefficient was found to be excellent $(\alpha=.94)$ and strong correlations between items $(r=.76, \mathrm{p}<.00)$. Factor loads of the scale items ranged from .66 to .93 . As a result, the related scale can be considered as a powerful scale that tests Measuring Problematic Mobile Phone Use: Development and Preliminary Psychometric Properties of the PUMP.

\subsection{Analysis of Data}

SPSS (Statistical Package for Social Sciences) version 23 was used to evaluate the data obtained from the study and to form the tables. Percentage (\%), mean $(\overline{\mathrm{x}})$, frequency (f) and standard deviation (SD) were used in the analysis of the data collected to respond to sub-objectives. Kolmogorov-Smirnov test p>.05 value was obtained; according to this it was accepted that the data shows normal distribution. In this context, parametric tests; One Way Anova test was used. The general average was taken into account in explaining the differences of the data.

In all statistical analyzes, the value of .05 was accepted as the level of significance. The mean and standard deviation values of the items for the related questionnaire are presented with the help of tables. 


\subsection{Sample Group}

In forming the sample group, proper sampling was used within the scope of purposeful sampling method in order to reach the purpose appropriately and easily. Appropriate sampling involves taking sampling elements that are easily accessible to the researcher (Monette, Sullivan and Dejong, 2005).

The sample of the study consists of 250 students studying at different departments in Hendek Vocational School of Sakarya University in the fall semester of 2019-2020.

Demographic data of Vocational School students are as follows:

\subsection{Demographic Data}

\section{Gender}

Of the 250 students who participated in the study, 189 were female and 61 were male.

\section{Age}

The sample consisted of 250 students who participated in the study, it was found that the age of 244 was in the range of "18-20" and 6 of them were in the range of "20 years and over".

\section{Department}

The sample consisted of 250 students who participated in the study, it was found that the department of 120 were "computer programming"; 44 were "construction" ; 49 were "electronic"; 37 were "machine".

\section{Computer Education}

It was found that the majority of the 250 students (166 students) from the sample group who participated in the study received computer education.

\subsubsection{Most Used Social Media Tools}

Table 1. Used Social Media Tools

\begin{tabular}{lll}
\hline Social Media Tools & F & $\mathbf{\%}$ \\
\hline Facebook & 3 & 1.2 \\
Instagram & 140 & 56.0 \\
Twitter & 8 & 3.2 \\
YouTube & 34 & 3.6 \\
Whatssapp & 64 & 25.6 \\
Others & 1 & .4 \\
Total & $\mathbf{2 5 0}$ & $\mathbf{1 0 0}$ \\
\hline
\end{tabular}

When the table above is examined, it is found that the most used social media tool of the students participating in the research is "Instagram".

2.4.2 How Many Years have you been Using a Smartphone

Table 2. Using Smartphone Year

\begin{tabular}{lll}
\hline Using Years & F & \% \\
\hline 1 year or less & 5 & 2.0 \\
1-2 year & 72 & 28.8 \\
3-4 year & 78 & 31.2 \\
5-6 year & 95 & 38.0 \\
6+ & 0 & 0.0 \\
Total & $\mathbf{2 5 0}$ & $\mathbf{1 0 0}$ \\
\hline
\end{tabular}

When the table above is examined, it is found that the year of use of smart phones of the students participating in the research is frequently "5-6 year. 


\subsubsection{Smart Phone Charging Time}

Table 3. Charging Time

\begin{tabular}{lll}
\hline Charging Time & F & \% \\
\hline Less than 2 hours & 134 & 53.6 \\
Every 2 hours & 99 & 39.6 \\
Every 3 hours & 5 & 2.0 \\
4 hours or more & 12 & 4.8 \\
Total & $\mathbf{2 5 0}$ & $\mathbf{1 0 0}$ \\
\hline
\end{tabular}

It has been determined that the duration of charging the smart phones of the students participating in the research is often "less than 2 hours".

\subsubsection{Number of Smartphones}

Table 4. Number of Smartphones

\begin{tabular}{lll}
\hline Number & F & \% \\
\hline 1 & 238 & 95.2 \\
2 & 9 & 3.6 \\
More than 2 & 3 & 1.2 \\
Total & $\mathbf{2 5 0}$ & $\mathbf{1 0 0}$ \\
\hline
\end{tabular}

When the table above is examined, it is determined that the number of smart phones used by the students is often "1".

\subsubsection{Keep Internet Always On}

Table 5. Keeping the Internet On

\begin{tabular}{lll}
\hline Internet & F & \% \\
\hline yes & 116 & 46.4 \\
no & 134 & 53.6 \\
Total & $\mathbf{2 5 0}$ & $\mathbf{1 0 0}$ \\
\hline
\end{tabular}

When the above table is examined, it is found that the majority of students "keep the internet on" their smart phones.

\subsubsection{Daily Time on Smartphones}

Table 6. Daily Use Time

\begin{tabular}{lll}
\hline Daily Use Time & F & \% \\
\hline 1-2 hour & 30 & 7.0 \\
3-4 hour & 79 & 29.7 \\
5-6 hour & 96 & 46.5 \\
6 hour and more & 45 & 16.8 \\
Total & $\mathbf{2 5 0}$ & $\mathbf{1 0 0}$ \\
\hline
\end{tabular}

When the table above is examined, it is found that the majority of the students spend on their smart phones "5-6 hours". 


\subsubsection{Smart Phones Control Range}

Table 7. Smart Phones Control Range

\begin{tabular}{lll}
\hline Control Range & F & $\mathbf{\%}$ \\
\hline Every 1 minutes & 2 & 17 \\
Every 2 minutes & 8 & 12.8 \\
Every 5 minutes & 10 & 3.4 \\
Every 10 minutes & 25 & 8.6 \\
Every 15 minutes & 18 & 6.2 \\
Every 20 minutes & 21 & 7.2 \\
Every 25 minutes & 2 & .7 \\
Every 30 minutes & 45 & 21.4 \\
Every 40 minutes & 2 & .7 \\
Every 45 minutes & 11 & 3.8 \\
Every 50 minutes & 5 & 1.7 \\
Every 1 hour & 62 & 32.8 \\
Every 80 minutes & 2 & .7 \\
Every 90 minutes & 4 & 1.4 \\
Every 100 minutes & 4 & 1.4 \\
Every 2 hour & 14 & 4.8 \\
Every 3 hour & 1 & .3 \\
Every 4 hour & 2 & .7 \\
4 hour and more & 2 & .7 \\
Total & $\mathbf{2 5 0}$ & $\mathbf{1 0 0}$ \\
\hline
\end{tabular}

When the table above is examined, it is determined that the control interval of the students' smart phones is often bir every "60 minutes".

2.4.8 Panic Status When You Forget the Smart Phone

Table 8. Panic Status

\begin{tabular}{lcl}
\hline Panic Status & F & \% \\
\hline yes & 117 & 46.8 \\
no & 133 & 53.2 \\
Total & $\mathbf{2 5 0}$ & $\mathbf{1 0 0}$ \\
\hline
\end{tabular}

Table 8 shows that the majority of students are "panic" when they forget their smart phones at home or at work.

2.4.9 Smartphone Usage Status while Driving

Table 9. Using a Smartphone while Driving

\begin{tabular}{lll}
\hline using while driving & F & \% \\
\hline yes & 98 & 39.2 \\
no & 152 & 60.8 \\
Total & $\mathbf{2 5 0}$ & $\mathbf{1 0 0}$ \\
\hline
\end{tabular}

According to the table above, the majority of students emphasized that they do not use smartphones while driving.

\subsubsection{Writing a Text-Message-E-mail While Driving}

Table 10. Writing Text-Message-E-mail While Driving

\begin{tabular}{lcl}
\hline Writing Text-Message-E-mail While Driving & F & \% \\
\hline yes & 40 & 16.0 \\
no & 210 & 84.0 \\
Total & $\mathbf{2 5 0}$ & $\mathbf{1 0 0}$ \\
\hline
\end{tabular}

According to the table above, the majority of students emphasized that they did not write text, messages and / or e-mail while driving. 


\subsubsection{Use of Purpose Smart Phones}

Table 11. Use of Purpose

\begin{tabular}{lll}
\hline Purpose & F & \% \\
\hline social media & 96 & 38.4 \\
e-mail & 3 & 11.2 \\
chat & 51 & 20.4 \\
messaging & 52 & 20.8 \\
reading news & 4 & 1.6 \\
playing & 9 & 3.6 \\
watching film & 6 & 2.4 \\
listening music & 21 & 8.4 \\
others & 8 & 3.2 \\
Total & $\mathbf{2 5 0}$ & $\mathbf{1 0 0}$ \\
\hline
\end{tabular}

When the above table is examined, it is determined that the students who participated in the research mostly use their smart phones for "social media ".

\section{Findings}

3.1 The Results of the Analysis of the Scale Items (Mean ( $\bar{x})$ and Standard Deviation (SD) values) are Given in Table 12.

Table 12. Measuring Problematic Mobile Phone Use: Development and Preliminary Psychometric Properties of the PUMP Scale Items

\begin{tabular}{lll}
\hline Item and Factors & $\overline{\mathrm{X}}$ & SD \\
\hline M17. I feel less satisfied when I use my smartphone less. & 2.60 & 1.026 \\
M18. I need more time to use my smartphone to make feel more satisfied. & 2.18 & 1.077 \\
M19. I become pessimistic and restless when I stop using my smartphone. & 2.07 & .971 \\
M20. I feel emotional, when I stop using my smartphone. & 1.87 & .948 \\
M21. When I spend my smartphone, my other important work is disrupted. & 2.69 & 1.257 \\
M22. When I think of the past, I think the time I spent with my smartphone is not normal. & 2.79 & 1.264 \\
M23. I believe I spend a lot of time with my smartphone. & 3.07 & 1.212 \\
M24. People (family, friends) say I spend a lot of time on my smartphone. & 2.31 & 1,167 \\
M25. When I'm not using my smartphone, I'm thinking of using it now or the next & 2.63 & 1.102 \\
time. & & \\
M26. I feel anxious when I'm not receiving calls or messages. & 2.12 & 1.171 \\
M27. When I use my smartphone, I notice that I ignore the people (family, friends) & 2.23 & 1.189 \\
who are with me. & & \\
M28. I use my smartphone when I need to do work or school work. & 4.09 & .807 \\
M29. I keep using my smartphone even though I know I need to sleep. & 2.85 & 1.364 \\
M30. I continue to use my smartphone again, thinking that my life was affected & 1.84 & .913 \\
when I stopped using my smartphone. & & \\
M31. I have problems at work or school because I use my smartphone a lot. & 1.93 & 1.015 \\
M32. I spend time with my smartphone instead of people who are important to me & 1.75 & 1.003 \\
and want to spend time with me. & & \\
M33. Even though I know that using a smartphone is dangerous, I keep using it. & 3.01 & 1.247 \\
M34. I almost caused an accident while using my smartphone. & 1.63 & .953 \\
M35. I think the smartphone is causing problems in my relationships. & 1.89 & .971 \\
M36. I keep using my smartphone even when someone asks me a question. & 1.71 & .921 \\
Overall Average & 2.80 & 1.07 \\
\hline
\end{tabular}

For 20 items and 3 dimensions, it was found that the mean values varied between 4.09 and 1.63. Score limits used in the interpretation of the results; "Strongly Disagree: 1.00-1.79"; "I disagree: 1.80-2.59"; "Undecided: 2.60-3.39"; "I agree: 3.40-4.19"; "Strongly Agree: 4.20-5.00" (Buyukozturk, 2013) values have been accepted. In this context, since the overall average of all items for the related scale is 2.80 , it is understood that the students' responses are generally focused on the "Undecided" option.

The scale with the highest average of 20 items "I use my smartphone when I need to do work or school work" 
although; the lowest average of the substance; "I almost caused an accident while using my smartphone" it was determined. From these results, it is understood that the students involved in the research are not smartphone addicts.

\subsection{The Effect of Demographic Characteristics of Students on Nomophobia Levels}

One-way Anova test was used to determine whether the demographic characteristics of the students had a significant effect on nomophobia levels. One Way Anova test; It is a test conducted to determine the effect of an independent variable with three or more levels on a continuous dependent variable (Buyukozturk, 2013).

\subsubsection{By Gender}

Table 13. Effect by Gender One-Way Anova Test Result

\begin{tabular}{lllllll}
\hline Sourceof Variation & Sumof Squares & sd & Mean Squares & F & p & Significant Difference \\
\hline Between group & 1.230 & 1 & 1.230 & 4.122 & .044 & There is no \\
Within group & 74.178 & 248 & .299 & & & significant difference. \\
Total & $\mathbf{7 5 . 4 0 8}$ & $\mathbf{2 4 9}$ & & & & \\
\hline
\end{tabular}

According to the results of one-way ANOVA test; it was found that nomophobia levels of students had no significant effect on gender ( $p>.05)$.

\subsubsection{By Age}

Table 14. Effect by Age One-Way Anova Test Result

\begin{tabular}{lllllll}
\hline Sourceof Variation & Sumof Squares & sd & Mean Squares & F & p & Significant Difference \\
\hline Between group & .216 & 1 & .216 & .712 & .400 & There is no \\
Within group & 75.192 & 248 & .303 & & & significant difference. \\
Total & $\mathbf{7 5 . 4 0 8}$ & $\mathbf{2 4 9}$ & & & & \\
\hline
\end{tabular}

According to the results of one-way ANOVA test; it has been shown that nomophobia levels of students do not have a significant effect according to age ( $>$ >.05).

\subsubsection{By Department}

Table 15. Effect by Department One-Way Anova Test Result

\begin{tabular}{lllllll}
\hline Sourceof Variation & Sumof Squares & sd & Mean Squares & F & p & Significant Difference \\
\hline Between group & .716 & 3 & .239 & .786 & .503 & There is no \\
Within group & 74.692 & 246 & .304 & & & significant difference. \\
Total & $\mathbf{7 5 . 4 0 8}$ & $\mathbf{2 4 9}$ & & & & \\
\hline
\end{tabular}

According to the results of one-way ANOVA test; it has been shown that nomophobia levels of students do not have a significant effect according to departments ( $p>.05)$.

\subsubsection{By Computer Education}

Table 16. Effect by Computer Education One-Way Anova Test Result

\begin{tabular}{lllllll}
\hline Sourceof Variation & Sumof Squares & sd & Mean Squares & F & p & Significant Difference \\
\hline Between group & .162 & 1 & .162 & .535 & .465 & There is no \\
Within group & 75.246 & 248 & .303 & & & significant difference. \\
Total & $\mathbf{7 5 . 4 0 8}$ & $\mathbf{2 4 9}$ & & & & \\
\hline
\end{tabular}

According to the results of one-way ANOVA test; it has been shown that nomophobia levels of students do not have a significant effect according to give computer education ( $p>.05)$.

\subsection{The Effect of Students' Smartphone Usage Habits on Nomophobia Levels}

One-way ANOVA test was used to determine whether the nomophobia levels of the students differed according to smartphone usage habits (smartphone usage year, charging interval, smartphone control interval). The results of these analyzes are given below. 


\subsubsection{Smart Phones by Year of Use}

Table 17A. By Smartphone Usage Year

\begin{tabular}{lllllll}
\hline Sourceof Variation & Sumof Squares & sd & Mean Squares & F & p & Significant Difference \\
\hline Between group & 5.159 & 3 & 1.720 & 6.022 & .001 & There is a \\
Within group & 70.249 & 246 & .286 & & & significant difference. \\
Total & $\mathbf{7 5 . 4 0 8}$ & $\mathbf{2 4 9}$ & & & & \\
\hline
\end{tabular}

According to the results of one-way ANOVA test; it has been shown that nomophobia levels of students have a significant effect on smartphone usage year $(\mathrm{p}<.05)$.

Table 17B. Comparative Results Between Subgroups Scheffe Test

\begin{tabular}{llllll}
\hline & Usage Year & Difference of order & $\mathrm{S}$ & $\mathrm{p}$ & Significant Difference \\
\hline \multirow{3}{*}{ 1-2 year** year } & .62069 & .24714 & .0750 & There is a \\
& 3-4 year & .05454 & .08733 & .1913 & significant difference. \\
& 5-6 year* & .28596 & .08350 & .0409 & \\
\hline
\end{tabular}

According to Scheffe test results; between levels of nomophobia and years of smartphone use; there was a significant difference between 1-2 years and 5-6 years of use $(\mathrm{p}<.05)$.

\subsubsection{By Charging Smartphones Interval}

Table 18A. Smartphone Charging Interval

\begin{tabular}{lllllll}
\hline Sourceof Variation & Sumof Squares & sd & Mean Squares & F & p & Significant Difference \\
\hline Between group & 7.025 & 3 & 2.342 & 8.356 & .000 & There is a \\
Within group & 68.382 & 246 & .280 & & & significant difference. \\
Total & $\mathbf{7 5 . 4 0 7}$ & $\mathbf{2 4 9}$ & & & & \\
\hline
\end{tabular}

According to the results of one-way ANOVA test; students' nomophobia levels were found to have a significant effect on the interval of charging smart phones $(\mathrm{p}<.05)$.

Table 18B. Comparative Results Between Subgroups Scheffe Test

\begin{tabular}{llllll}
\hline & Charging Interval & Difference of order & $\mathbf{S}$ & $\mathbf{p}$ & Significant Difference \\
\hline \multirow{3}{*}{ t time $^{*}$} & 2 time & .33885 & .07016 & .000 & There is a \\
& 3 time & .01418 & .24113 & 1.000 & significant difference. \\
& 4 time and more* & .33582 & .17354 & .293 & \\
\hline
\end{tabular}

When Table 18.1 is examined, according to Scheffe test results; charging times for smartphones with nomophobia levels; there was a significant difference in charge intervals between 1 time and 4 times and more a day $(\mathrm{p}<.05)$.

\subsubsection{By Smartphone Check Interval}

Table 19A. Smartphone Check Interval

\begin{tabular}{lllllll}
\hline Sourceof Variation & Sumof Squares & sd & Mean Squares & F & p & Significant Difference \\
\hline Between group & 14.122 & 15 & .941 & 3.595 & .000 & There is a \\
Within group & 61.286 & 234 & .262 & & & significant difference. \\
Total & $\mathbf{7 5 . 4 0 8}$ & $\mathbf{2 4 9}$ & & & & \\
\hline
\end{tabular}

According to the results of one-way ANOVA test; it was revealed that the students' levels of nomophobia had a significant effect on the interval of check their smart phones $(\mathrm{p}<.05)$. 
Table 19B. Comparative Results Between Subgroups Scheffe Test

\begin{tabular}{llllll}
\hline & Check Interval & Difference of order & S & p & Significant Difference \\
\hline Every 5 & Every 60 minute* & .42110 & .06012 & .000 & There is a \\
minutes * & Every 2 hour* & .02311 & .04100 & .001 & significant difference. \\
& Every 3 hour* & .13080 & .07224 & .003 & \\
& Every 4 hour* & .31023 & .13509 & .000 & \\
\hline
\end{tabular}

When Table 19.1 is examined, according to Scheffe test results; control of smartphones with nomophobia levels; There was a significant difference between the control intervals every $5 \mathrm{~min}$ to $60 \mathrm{~min}$, every 2 hours, every 3 hours and every 4 hours $(\mathrm{p}<.05)$.

\subsubsection{Panic Status When You Forget the Smart Phone}

Table 20. Panic Status

\begin{tabular}{lllllll}
\hline Sourceof Variation & Sumof Squares & sd & Mean Squares & F & p & Significant Difference \\
\hline Between group & 4.204 & 1 & 4.204 & 14.641 & .000 & There is a \\
Within group & 71.204 & 248 & .287 & & & significant difference. \\
Total & $\mathbf{7 5 . 4 0 8}$ & $\mathbf{2 4 9}$ & & & & \\
\hline
\end{tabular}

According to the results of one-way ANOVA test; it was revealed that the students' nomophobia levels had a significant effect according to their panic status when they forgot their smart phones $(\mathrm{p}<.05)$.

\subsection{Relationship Between Smartphone Charging Interval and Nomophobia Level Pearson Correlation Coefficient Result}

Table 21. Relationship Between Charging Interval and Nomophobia Level

\begin{tabular}{llll}
\hline & $\mathrm{N}$ & $\mathrm{R}$ & $\mathrm{p}$ \\
\hline $\begin{array}{l}\text { Nomophobia Level } \\
\text { Charging Interval }\end{array}$ & 250 & .230 & .000 \\
\hline
\end{tabular}

As shown in the table above, a positive and significant relationship was found between students' nomophobia levels and smartphone charging intervals $(r=.230$ and $\mathrm{p}<0.01)$.

\subsection{Relationship Between Smartphone Checking Interval and Nomophobia Level Pearson Correlation Coefficient Result}

Table 22. Relationship Between Checking Interval and Nomophobia Level

\begin{tabular}{llll}
\hline & $\mathrm{N}$ & $\mathrm{R}$ & $\mathrm{p}$ \\
\hline $\begin{array}{l}\text { Nomophobia Level } \\
\text { Checking Interval }\end{array}$ & 250 & .302 & .000 \\
\hline
\end{tabular}

As shown in the table above, a positive and significant relationship was found between students' nomophobia levels and smartphone checking intervals $(r=.302$ and $\mathrm{p}<0.01)$.

\subsection{Relationship Between Panic Status and Nomophobia Level Pearson Correlation Coefficient Result}

Table 23. Relationship Between Panic Status and Nomophobia Level

\begin{tabular}{llll}
\hline & $\mathrm{N}$ & $\mathrm{R}$ & $\mathrm{p}$ \\
\hline $\begin{array}{l}\text { Nomophobia Level } \\
\text { Panic Status }\end{array}$ & 250 & .236 & .000 \\
\hline
\end{tabular}

As shown in the table above, a positive and significant relationship was found between students' nomophobia levels and panic status $(\mathrm{r}=.236$ and $\mathrm{p}<0.01)$.

\section{Result and Discussion}

In this study, which was tried to determine the nomophobia levels of the students, the appropriate sampling method was used as the sampling method and in this context, 250 students from different departments of Sakarya University Hendek Vocational School were studied. The results of the research are given below: 
In this study, it has been tried to determine the changes in nomophobia levels of students according to demographic characteristics and smartphone usage habits. Accordingly, it was revealed that the most used social media tool of the students was "Instagram". Instagram was founded in 2010 by two entrepreneurs named Kevin Systrom and Mike Krieger. Previously a free photo sharing and photo editing application made for iphone, then this application has become available on android platform devices. As the celebrities shared their daily life photos through this software, there was a rapid increase in the number of followers on Instagram. Instagram can be viewed within the scope of photo and video sharing networks within social media networks (Can, 2017) and on the basis of photo sharing, it has become one of the increasingly widespread social media channels with access in the global world (Latif and Safiee, 2015). Today it is the fastest growing social networking site globally. As a similar result, Kuyucu (2016) found that instagram was the most commonly used social media environment for university students. In their research, Ibiş and Engin (2016) found that the most commonly used social media environment of university students was "facebook".

When the smartphone usage habits of the students were examined; it was determined that the smartphone usage year was between "5-6 years". As a similar result, Sirakaya (2018) found that the density of smartphone use of associate degree students is 5 years or more. The control interval of the students' smart phones is often determined as bir every 60 minutes. Contrary to this result, Strakaya showed that this control period is usually 1-19 minutes. Studies have shown that the majority of smartphone users do not hang up even at night (Dixit et al., 2010; Kaur et al., 2015; King et al., 2013). Contrary to these findings, it is understood that the students involved in the research are not smartphone addicts.

The frequency of students charging their smartphones is "less than 2 hours"; their daily use was determined as "5-6 hours". In addition, the number of smartphone owned by the majority of students was determined to be "1 number". According to TurkStat (2019) data, 98\% of adult people use mobile phones, $77 \%$ of them use smart phones. Apart from these, it was found that individuals spend an average of 7 hours per day on the internet and spend an average of 2 hours 46 minutes on social media, 3 hours 9 minutes on television and 1 hour 15 minutes of listening to music per day. Durak and Seferoglu (2018) found that the majority of middle school students use their smart phones less than 1 hour daily and frequently check them at 2-3 hour intervals.

In the research, it was revealed that the majority of students don't keep the internet open on their smart phones. The aims of using the internet are mostly defined as "social media". Most of the students stated that they did not experience panic when they forgot their smart phones in one place, they did not use their smart phones while they were driving and they did not write mail-text-messages. These results support that the students involved in the research are not smartphone addicts.

In this research, the scale with the highest average of 20 items "I use my smartphone when I need to do work or school work" although; the lowest average of the substance; "I almost caused an accident while using my smartphone" it was determined. From these results, it is understood that the students involved in the research are not smartphone addicts.

In terms of evaluating the effect of demographic characteristics of students on nomophobia levels, it was revealed that students' nomophobia levels had no significant effect on their gender. Yılmaz, Köse and Doğru (2018) found that women's nomophobia levels differ significantly from men. When a comparison was made between the dimensions in terms of gender variable, a significant difference was found between men and women in the dimensions of "loss of communication and lack of device". Nomophobia levels of loss of communication and device deprivation in were significantly higher in women than men. In addition, it was found that nomophobia levels of the students had no significant effect according to age and departments. Yilmaz, Kose and Dogru (2018) have revealed a negative and significant relationship between age and nomophobia in their research.

In the study, in the context of examining nomophobia levels of students according to smartphone usage habits; It was found that there was a significant difference between students' smartphone usage year, charging intervals, control time, panic state when they left their smart phones somewhere and their nomophobia levels. In addition, Pearson Correlation Coefficient was used to determine the relationship between these variables. There was a significant and positive relationship between the related variables and students' nomophobia levels. When the literature is examined, Sirakaya (2018) found that there is a significant difference between the range of controlling smartphones and nomophobia, and that as the frequency of controlling increases, nomophobia increases.

\section{Suggestions}

Suggestions put forward according to the results of the research are presented below: 
- The effects of smart phones on human life and the features that facilitate social life are undeniable. In addition, the presence of many entertainment-based applications in smartphones do not influence users. This may lead to many negative psychological problems such as asociality, loneliness and depression. In this context, users should not be exposed to smart phones continuously in their spare time, they should be open to real social relations.

- In this study, it was determined that the students were not dependent in terms of using smart phones and their nomophobia levels were not high level. However, it is seen that this concept has become widespread especially among young people today. Especially considering the time periods when they use smart phones, it is recommended to raise awareness of young people by experts in this field and to organize awareness activities by relevant institutions and organizations.

\section{References}

Adnan, M., \& Gezgin, D. M. (2016). Modern yüzyılın yeni olgusu nomofobi ve üniversite öğrencileri arasında yaygınlık düzeyi. Ankara Üniversitesi Eğitim Bilimleri Fakültesi Dergisi, 49(1), 141-158. https://doi.org/10.21764/efd.80423

Akman, E. (2019). Akıllı Telefonsuz Kalma Korkusunun (nomofobi) Akademik Başarıya Etkisi: Süleyman Demirel Üniversitesi Siyaset Bilimi ve Kamu Yönetimi Öğrencileri Üzerinden Bir Değerlendirme. Avrasya Uluslararası Araştırmalar Dergisi, 7(16), 256-275. https://doi.org/10.33692/avrasyad.543756

Anshari, M., Alas, Y., Hardaker, G., Jaidin, J. H., Smith, M., \& Ahad, A. D. (2016). Smartphone habit and behavior in Brunei: Personalization, gender, and generation gap. Computers in Human Behavior, 64, 719-727. https://doi.org/10.1016/j.chb.2016.07.063

Burucuoğlu, M. (2017). Meslek Yüksekokulu Öğrencilerinin Nomofobi Düzeyleri Üzerinde Bir Araştırma. Karabük Üniversitesi Sosyal Bilimler Enstitüsü Dergisi, 7(2), 482-486. https://doi.org/10.14230/joiss423

Büyüköztürk, Ş. (2013). Sosyal bilimler için veri analizi el kitabı. Ankara: Pegem Akademi Yayıncılık.

Can, L. (2017). Sosyal Medya Pazarlaması Kanalı olarak Instagram'da Algılanan Sürü Davranışı ve Satın Alma Niyeti. Akademik Bakış Dergisi, 59, 209-219. http://dx.doi.org/10.17130/ijmeb.2018239947

Creswell, J. W. (2014). Araştırma deseni: Nitel, nicel ve karma yöntem yaklaşımları (S. B. Demir, çev). Ankara: Eğiten Kitap.

Çelik, Y., \& Atilla, G. (2018). Üniversite Öğrencilerinin Nomofobi, Duygu Düzenleme Güçlüğü ve Akademik Başarıları Arasındaki İlişkinin İncelenmesi. International Journal of Social Humanities Sciences Research, 5(26), 2628-2638. https://doi.org/10.26450/jshsr.674

Dixit, S., Shukla, H., Bhagwat, A. K., Bindal, A., Goyal, A., Zaidi, A. K., \& Shrivastava, A. (2010). A study to evaluate mobile phone dependence among students of a medical college and associated hospital of central India. Indian Journal of Community Medicine: Official Publication of Indian Association of Preventive \& Social Medicine, 35(2), 339. http://dx.doi.org/10.4103/0970-0218.66878

Durak, H., \& Seferoğlu, S. (2018). Ortaokul öğrencilerinin akıllı telefon kullanımları ve bağımlılık düzeyleriyle ilgili bir inceleme [An examination of smartphone use and addiction among middle school students]. Educational Technology Theory and Practice, 8(1), 1-23. https://doi.org/10.17943/etku.288822

Gezgin, D. M., \& Çakır, Ö. (2016). Analysis of nomofobic behaviors of adolescents regarding various factors. Journal of Human Sciences, 13(2), 2504-2519. https://doi.org/10.14687/jhs.v13i2.3797

İbiş, S., \& Engin, Y. (2016). Öğrencilerin Yiyecek ve İçecek İşletmesi Seçiminde Sosyal Medyanın Rolünün Belirlenmesi. Mehmet Akif Ersoy Üniversitesi Sosyal Bilimler Enstitüsü Dergisi, 8(17), 322-336. https://doi.org/10.20875/sb.68247

Kaplan-Akıllı, G., \& Gezgin, D. M. (2016). Üniversite öğrencilerinin nomofobi düzeyleri ile farklı davranış örüntülerinin arasındaki ilişkilerin incelenmesi. Mehmet Akif Ersoy Üniversitesi Ĕ̆itim Fakültesi Dergisi, 40, 51-69. https://doi.org/10.21764/efd.80423

Kaur, A., Sharma, P., \& Manu. (2015). A descriptive study to assess the risk of developing nomophobia among students of selected nursing colleges Ludhiana, punjab. International Journal of Psychiatric Nursing, 1(2), 1-6. https://doi.org/10.5958/2395-180X.2015.00051.1

King, A. L. S., Valença, A. M., Silva, A. C. O., Baczynski, T., Carvalho, M. R., \& Nardi, A. E. (2013). Nomophobia: Dependency on virtual environments or social phobia? Computers in Human Behavior, 29(1), 140-144. https://doi.org/10.1016/j.chb.2012.07.025 
Kuyucu, M. (2016). Instagram Radyonun Gizemini Öldürdü Mü? Radyo Kanalları ve Radyo Programcılarında Intagram Kullanımı. Ulakbilge, 4(7), 69-97. https://doi.org/10.7816/ulakbilge-04-07-05

Kwon, M. (2013). Development and validation of a smartphone addiction scale (SAS). PLoS One, 8(2), 1-7. https://doi.org/10.1371/journal.pone.0056936

Latiff Z. A., \& Safiee N. A. S. (2015). New Business Set Up for Branding Strategies on Social Media Instagram. Procedia Computer Science, 72, 13-23, https://doi.org/10.1016/j.procs.2015.12.100

Lee, Y. K., Chang, C, T., Lin, Y., \& Cheng, Z. H. (2014). The dark side of smartphone usage: psychological traits, compulsive behavior and technostress. Computers in Human Behavior, 31, 373-383. https://doi.org/10.1016/j.chb.2013.10.047

Monette, D. R., Sullivan, T. J., \& De Jong, C. R. (2005). Applied Social Research. New York: Harcourt Broce Jovanovich, Inc.

Pavithra, M. B., Madhukumar, S., \& Mahadeva, M. (2015). A study on nomophobia-mobile phone dependence, among students of a medical college in Bangalore. National Journal of Community Medicine, 6(3), 340-344. http://dx.doi.org/10.18203/2394-6040.ijcmph20191814

Schifferstein, H. N. J. (2006). The perceived importance of sensory modalities in product usage: a study of self-reports. Acta Psychologica, 121, 41-64. https://doi.org/10.1016/j.actpsy.2005.06.004

Sırakaya, M. (2018). Ön lisans öğrencilerinin nomofobi düzeylerinin akıllı telefon kullanım durumlarına göre incelenmesi. Mersin University Journal of the Faculty of Education, 14(2). https://doi.org/10.17860/mersinefd.359458

Sharma, N., Sharma, P., Sharma, N., \& Wavare, R. R. (2015). Rising concern of nomophobia amongst Indian medical students. International Journal of Research in Medical Sciences, 3(3), 705-707. https://doi.org/10.5455/2320-6012.ijrms20150333

Takao, M., Takahashi, S., \& Kitamura, M. (2009). Addictive personality and problematic mobile phone use. Cyber Psychology \& Behavior, 12(5), 501-507. https://doi.org/10.1089/cpb.2009.0022

Tavolacci, M. P., Meyrignac, G., Richard, L., Dechelotte, P., \& Ladner, J. (2015). Problematic use of mobile phone and nomophobia among French college students. The European Journal of Public Health, 25(suppl 3), ckv172-088. https://doi.org/10.1093/eurpub/ckv172.088

Thomee, S., Harenstam, A., \& Hagberg, M. (2011). Mobile Phone Use and Stress, Sleep Disturbances and Symptoms of Depression Among Young Adults: A Prospective Cohort Study. BMC Public Health, 66, 1-11. http://dx.doi.org/10.18203/2394-6040.ijcmph20191814

Yildirim, C. \& Correia, A.-P. (2015). Correia Exploring the dimensions of nomophobia: Development and validation of a self-reported questionnaire. Computers in Human Behavior, 49(2015), 130-137. https://doi.org/10.1016/j.chb.2015.02.059

Yıldırım, Ç., Sumuer, E., \& Adnan, M. (2015). A growing fear: Prevalence of nomophobia among Turkish college students. Information Development, 32(5), 1322-1331. https://doi.org/10.1177/0266666915599025

Yılmaz, M., Köse, A., \& Doğru, Y. B. (2018). Akıllı Telefondan Yoksun Kalmak: Nomofobi Üzerine Bir Araştırma. Informatics and Communication Technologies, 9(35).

https://doi.org/10.5824/1309-1581.2018.5.003

\section{Copyrights}

Copyright for this article is retained by the author(s), with first publication rights granted to the journal.

This is an open-access article distributed under the terms and conditions of the Creative Commons Attribution license (http://creativecommons.org/licenses/by/4.0/). 